\title{
Patenting in England, Scotland and Ireland during the Industrial Revolution, \\ 1700-1852
}

Sean Bottomley 


\title{
Patenting in England, Scotland and Ireland during the Industrial Revolution, 1700-1852
}

\begin{abstract}
There are two competing accounts for explaining Britain's technological transformation during the Industrial Revolution. One sees it as the inevitable outcome of a largely exogenous increase in the supply of new ideas and ways of thinking. The other sees it as a demand side response to economic incentives - that in Britain, it paid to invent the technology of the Industrial Revolution. However, this second interpretation relies on the assumption that inventors were sufficiently responsive to new commercial opportunities. This paper tests this assumption, using a new dataset of Scottish and Irish patents. It finds that the propensity of inventors to extend patent protection into Scotland and/or Ireland was indeed closely correlated with the relative market opportunity of the patented invention.
\end{abstract}

\section{Introduction}

Economists frequently approximate human behaviour as that of an elemental Homo economicus, that people behave as rational utility maximisers. In endogenous growth theory and other studies of technological change, inventors are assumed to behave in an analogous manner; as Paul Romer explains: 'technological change arises in large part because of intentional actions taken by people who respond to market incentives'. ${ }^{1}$ Historians are more reluctant to reduce human intent and action to simple profit-maximisation, understanding that individuals (and inventors) are often animated by a myriad of motivating factors, be it public acclaim, intellectual fulfilment, even altruism.

Where the two disciplines meet, there is inevitably dissonance - perhaps nowhere more so than in treatments of the Industrial Revolution, where this (simplified) scission on the motivations of inventors is mirrored in two broad approaches to explaining technological development. The first can be seen as a 'demandside' explanation - that in Britain, and only in Britain, was it profitable to invent the technology of the Industrial Revolution. The most influential exponent of this view is Bob Allen. Allen notes that compared with other countries, Britain had a unique structure of factor prices - labour was expensive, while capital and energy were cheap. Accordingly, technological change was biased towards increasing the capital-labour ratio and this labour-saving technology was ultimately the progenitor of the Industrial Revolution. ${ }^{2}$ In a similar vein, Daron Acemoğlu, suggests that the large scale migration of labour from the countryside and Ireland into English towns and cities induced the development of technologies that allowed manufacturers to replace skilled labour with unskilled labour. ${ }^{3}$ This interpretation, however, is critically dependent on the assumption that inventors were sufficiently attuned to specific economic opportunities. In attributing the development of technology to

Romer (1990, S72).

2 'Britain's high wages and cheap energy increased the demand for technology by giving British businesses an exceptional incentive to invent techniques that substituted capital and energy for labour'. Allen $(2009,15)$.

3 Acemoğlu (2002, 797-98). 
economic imperatives, Deirdre McCloskey accuses Allen of 'reductionism'. ${ }^{4}$ She emphasises instead, how new 'bourgeois' ideals and rhetoric increased the supply of enterprise and innovation. Joel Mokyr also argues for the primary importance of the supply of ideas, stressing that although 'factor prices might have determined the direction of technological change, the power and intensity of improvements were a function of technological capabilities and motives that had deeper causes'. ${ }^{5}$ These motives were not necessarily financial: 'when the decisions [to invent] were made largely by independent individuals, ambition, curiosity, and altruism may have had a larger role relative to naked greed'. ${ }^{6}$

The primary purpose of this paper is to examine the responsiveness of inventors to market signals using a comparative analysis of the English, Scottish and Irish patent series - although in so doing, the paper also provides the first analysis of the Scottish and Irish patent systems during the Industrial Revolution. ${ }^{7}$ The following section describes the patent systems in each of the three countries. It shows that the administration and law of patents were essentially the same in all three, meaning that direct comparisons between the three countries' patent series is possible. The third section outlines the compilation of the Scottish and Irish patent series, which have not been previously available. The fourth section provides a statistical overview of the three patent series. It shows that the number of patents awarded in Scotland increased precipitously during the 1830s, the same time as when Scottish manufacturing began to industrialise. ${ }^{8}$ This suggests that inventors were responding to developments in Scotland, and were determined to pursue returns there via patenting. The final section analyses this proposition in more detail, examining the quality of patents that were extended to Scotland and Ireland, and the pro-cyclicality of annual patent totals.

\section{The administration and law of patents in England, Scotland and Ireland}

Modern patent systems are run by a single office, responsible for the examination, awarding and cataloguing of patents. Before the 1852 Patent Law Amendment Act, there was no equivalent to such an administration in the United Kingdom. Rather, patenting was administered by a slew of government offices, departments and law courts. These offices were not run by technically qualified professionals but by amateur gentlemen who often sub-contracted the clerical work to deputies. ${ }^{9}$ Further, England, Scotland and Ireland each maintained separate patent administrations. To secure an English patent, a petition had to pass through ten distinct stages, briefly:

4 And McCloskey quotes a letter written by the chemist Claude Louis Berthollet to James Watt, advising him that 'When one loves science ... one has little need for fortune which would risk one's happiness'. McCloskey (2011, 346-47). Watt, however, failed to heed this advice, patenting many of his inventions - most famously the separate condenser for steam engines - and enforcing them rigorously against other engineers, thereby making his fortune.

5 Mokyr, (2009, 272).

6 Mokyr $(2005,322)$. Elsewhere, however, Mokyr admits that 'Allen's basic assumption that inventive activity was driven by a desire to make money is not controversial'. Mokyr $(2009,270)$.

7 On the English patent system, see Dutton (1984) and MacLeod $(1988,1991)$. For a more positive précis of the pre-reform English patent system, see Bottomley (2014). On patenting in Scotland, there is one essay that includes a discussion of Scottish patent law, MacQueen (2010). To my knowledge, there has been no work on patents for inventions in Ireland during this period.

8 Devine $(2004,399)$.

9 For a more detailed description of the English petition procedure, see Bottomley (2014) 
$1^{\text {st }}$ stage. The inventor submitted his petition and affidavit. The petition provided a brief description of the invention, the name(s) of the petitioner(s), and the circumstances on which the claim to a patent was founded i.e. whether the petitioner was the original inventor or an importer. Before 1782, the petition and affidavit were submitted to either one of the two Secretaries of State. In 1782, when their responsibilities were divided between the Foreign Office and the Home Office, the petition and affidavit were submitted to the latter.

$2^{\text {nd }}$ stage. Once the petition was signed by the Secretary of State, it was referred to the Attorney or Solicitor-General (the law officers) to investigate and report upon.

$3^{\text {rd }}$ stage. The report was returned to the Home Office to receive the King's Warrant. The warrant was signed by the monarch and countersigned by the Secretary of State.

$4^{\text {th }}$ stage. The warrant was taken to the Patent Bill Office where a bill for the patent was prepared.

$5^{\text {th }}$ stage. The bill was taken to the Secretary of State. Here it received the royal signature and the sign manual. With the sign manual affixed, the bill was now entitled the 'The King's Bill'.

$6^{\text {th }}$ stage. The King's Bill was taken to the Signet Office, where the Signet Bill was prepared.

$7^{\text {th }}$ stage. The Signet Bill was taken to the Privy Seal Office, where the Privy Seal Bill was prepared.

$8^{\text {th }}$ stage. The Privy Seal Bill was taken to the Letters Patent Office where the patent document itself was prepared and enrolled.

$9^{\text {th }}$ stage. The patent was sealed by the Lord Chancellor and awarded to the petitioner.

$10^{\text {th }}$ stage. The patentee submitted their specification (a detailed description of the patented invention) at the Court of Chancery. If a specification was not entered, the patent was invalidated. From 1810, if only applying for an English patent, an inventor was awarded two months after the patent had been sealed to enter the specification. If applying for English and Scottish patents they were awarded four months and if applying for patents in England, Scotland and Ireland, six months. ${ }^{10}$ The additional time was granted because specification of the invention in England constituted an act of publication throughout the United Kingdom. Consequently, if the English patent was specified before the Scottish or Irish patent had been sealed, the latter would be technically invalid.

This procedure had been laid down by the Clerks of the Signet and Privy Seal Act (1535), which was itself based on long-established practice. ${ }^{11}$ Rather than provide an efficient and expeditious service, the Privy Seal Act established a convoluted petition so that non-salaried government officers could be supported by

10 Before 1810 there was no standard practice concerning the length of time patentees had in which to enter their specification. In 1780, every patentee was given four months to enter their specification, whereas in 1790 the norm was one month only (although a few were given two months). Woodcroft (1854).

11 Evidence from 1404-05 shows that the process for many patents and grants under the Great Seal began with a written petition presented directly to the King, who then conveyed his decision, by means of a Signet Bill, to the keeper of the Privy Seal. The decision was in turn conveyed to the Lord Chancellor by means of a Privy Seal Bill and this bears a close resemblance to the sixth, seventh, eighth and ninth stages of the petition procedure outlined here. Brown (1964, 140-41). 
charges levied on petitioners. ${ }^{12}$ The petition was not reformed until 1852, and obtaining an English patent was often arduous and time-consuming. In the eighteenth century, it could take six months to secure a patent, although the time required did decline. By 1829, it took around two months to have the patent sealed, and in 1849 , the reported average had fallen again to around one month. ${ }^{13}$

The granting of English patents for inventions was confirmed by the Statute of Monopolies in 1624 and a corresponding Act was passed by the Parliament of Scotland in $1641 .{ }^{14}$ The petition procedure in Scotland was markedly similar to that of England:

$1^{\text {st }}$ stage. The petition and affidavit of the inventor were submitted to the Home Office in London.

$2^{\text {nd }}$ stage. The petition was referred to the Lord Advocate of Scotland (the Scottish equivalent to the English Attorney-General) to investigate and report upon.

$3^{\text {rd }}$ stage. The report was taken to the Home Office where the King's Warrant was prepared, directing preparation of the patent.

$4^{\text {th }}$ stage. The patent was prepared in the office of the Director of the (Scottish) Chancery Office.

$5^{\text {th }}$ stage. The patent was taken to the Keeper of the Great Seal of Scotland, to be sealed and awarded to the petitioner.

$6^{\text {th }}$ stage. The specification was entered at the Chancery Office. As in England (and Ireland), two months were awarded for entering the specification if a patent was only obtained in Scotland, four months if a patent was sought in another country, and six months if patents were sought in all three countries. ${ }^{15}$

In 1845, it took about six weeks to obtain a Scottish patent. ${ }^{16}$ In contrast to England and Scotland, there does not appear to have been any statutory basis for Irish patents of inventions; certainly, there was no legislation dealing specifically with patents before the 1801 Act of Union. ${ }^{17}$ Nonetheless, the procedure was again similar to those in England and Scotland:

$1^{\text {st }}$ stage. The petition and affidavit were submitted to the Lord-Lieutenant of Ireland.

$2^{\text {nd }}$ stage. The petition was referred to the Attorney or Solicitor-General for Ireland (the Irish law officers) to investigate and report upon.

12 MacLeod $(1988,40)$.

13 House of Commons (1849, XXII:30).

14 Although the Act discharged all 'monopolies prejudicial to the public', it did not 'call in question or abridge the right of the Crown to grant patents for useful inventions but left that matter, without any statutory restriction, to be regulated, as before, by the principles of and practice of the common law'. Hayward (1988), 4:48. A copy of the Act (entitled simply 'Act discharging monpolies'), is available online at http://www.rps.as.uk/mss/1641/8/192.

15 House of Commons (1849, XXII:xii).

16 Billing and Prince $(1845,88)$.

17 In 1794, the patent agent James Poole sought counsel opinion on what the legal basis of Irish patent was. One lawyer, confirmed that 'although there is not a statute in Ireland impowering his majesty to grant letters patent for securing the exclusive right of new inventions for 14 years, yet by the common law I am of opinion all men have an exclusive property in rights of their own genius'. BIPC. Case book of James and Moses Poole, 1786$1825,3$. 
$3^{\text {rd }}$ stage. On receipt of the report, a draft of the King's letter was prepared and forwarded to the Home Office in London.

$4^{\text {th }}$ stage. The King's letter, consisting of the authority to grant the patent, was signed by the monarch and countersigned by the Secretary of State to the Home Office

$5^{\text {th }}$ stage. The King's Letter was entered at the Signet Office, sealed with the Signet, and returned to the Lord-Lieutenant.

$6^{\text {th }}$ stage. On receipt of the King's letter, a warrant was directed to the Attorney or Solicitor-General for Ireland, authorising him to draw up a fiant (a warrant) containing a grant from the King.

$7^{\text {th }}$ stage. The fiant was sent to the Lord-Lieutenant to be signed, and to have the Privy Seal affixed.

$8^{\text {th }}$ stage. The fiant was forwarded to the Clerk of the Crown, to have the patent document prepared, sealed and awarded to the petitioner.

$9^{\text {th }}$ stage The specification was entered at the Irish Court of Chancery. ${ }^{18}$

In 1845 , it averaged between six and eight weeks to obtain an Irish patent. ${ }^{19}$ Although the formal procedure for each country was different, the essential steps were the same. Most importantly, in all three countries, the substantive examination of the petition was undertaken by the law officer(s). Although it was unusual for the law officer to investigate the petition on their own initiative, it was common for private parties to oppose petitions obliging the law officers to hold private hearings. These hearings were primarily concerned with divining the novelty of the petitioner's invention and occasionally the law officers consulted expert opinion. Isambard Kingdom Brunel and Michael Faraday for example, were both called upon to assist with these hearings. ${ }^{20}$ The five law officers also consulted one another on matters relating to patents, ensuring a degree of uniformity in these proceedings and in the standards of patentability. Consequently, English administrative developments were adopted in Scotland and Ireland as well. The most significant change in the English petition before reform was the introduction of the specification, which became mandatory in the 1730s. Although very few Scottish and Irish patents were awarded in the first half of the eighteenth century, specifications were soon adopted in both countries where, as in England, they had to be entered at Chancery. ${ }^{21}$

The petition in all three countries was also bureaucratic and time-consuming. Scrutiny of the petition was largely confined to the report of the law officers, rendering most of these stages practically useless. Further, the petitioner was responsible for physically transmitting the petition, and the relevant documents, at every stage of the petition. ${ }^{22}$ This requirement imposed a heavy burden on patentees, especially for those resident outside London (or Edinburgh and Dublin). The diary of one inventor from the early eighteenth century

18 House of Commons (1849, XXII:xii).

19 Billing and Prince $(1845,88)$.

20 House of Commons (1849, XXII:32).

21 From 1728, all Irish patents were awarded on the condition that a specification was entered. State Papers. State Papers Domestic, George II, SP36/5:259. Similarly, the last Scottish patent without a specification was awarded in 1736. Chancery. Scottish patents and specifications, 1712-1812, 1.

22 The only exception to this was when the Signet Bill had to be moved to the Privy Seal Office at the eighth stage of the English petition. Hindmarch $(1846,527)$. 
indicates he spent five months in London petitioning for his patent. ${ }^{23}$ The advent of patent agency, however, obviated the need for inventors to attend their petition personally. Early patent agents were often clerks involved with the patent administration, and were ideally placed to conduct petitions on behalf of inventors. This made patent protection much easier for inventors to obtain; in 1829 one agent testified before a parliamentary select committee, 'the only acts the inventor is obliged to perform himself, are the making of an affidavit...paying his money... and afterwards, making out, acknowledging and signing the specification' and this could be done by post. ${ }^{24}$ The first London agent was James Poole who began practicing in the 1770s, and a number of English agencies maintained offices in Edinburgh and Dublin as well..$^{25}$

There was, however, no escaping the tremendous cost of maintaining this labyrinth. Every office charged petitioners to use their services, and in 1849, the minimum amount payable in office fees for an English patent was $£ 9917 \mathrm{~s} .6$ d. ${ }^{26}$ Calculated as a multiple of average earnings this equated to around $£ 70,000$ in $2013 .{ }^{27}$ In the same year office fees for a Scottish patent cost slightly less at $£ 633 \mathrm{~s}$. 7d., and in Ireland slightly more at $£ 11617 \mathrm{~s}$. 7d. Conveniently, the fees were rarely adjusted, meaning that the costs varied little over time. In 1808 for instance, the fees for an English patent amounted to $£ 9714$ s. 6d. or $£ 80,000$ in 2013 prices. Although there is less evidence for Scotland and Ireland it appears that fees remained generally stable there as well. In 1829 the office fees on a Scottish patent were $£ 62$ 8s. $11 \mathrm{~d}{ }^{28}$

Patentees, however, had to pay a great deal more than just the office fees. Firstly, they had to pay fees for patent agents. These amounted to 10 guineas for every individual English, Scottish or Irish patent. Secondly, a patentee had to pay fees to prepare and enter their specification. Patentees invested large sums in hiring technical assistance in preparing the specification. This was because in the event of legal action, the validity of the patent hinged upon its accuracy. In 1829, one patent agent claimed that he had known charges for preparing the specification to have been as high as $£ 200$, and reckoned the average to be around $£ 20 .{ }^{29}$ The reported average was the same in 1851, but again there were a minority of cases where the costs could be tremendous. Patentees also had to pay fees when submitting the specification to Chancery. The fees varied according to the length of the specification making it difficult to provide a representative figure for the average cost of entering a specification, although the minimum was reportedly $£ 20$. Thirdly, there were a raft of additional charges that could be incurred. For example, offices charged for 'expedition' in the processing of the petition. In the Privy Seal Office (where there was only enough business to occupy the clerks for an hour a

3 Gomme (1937).

4 House of Commons (1829, III:16).

25 House of Commons (1849, XLV:52). James Poole was involved with Irish and Scottish patents in the eighteenth century as well. BIPC. Case book of James and Moses Poole, 1786-1825, 3.

26 House of Commons (1849, XLV:79).

27 There are several methods of translating historical monetary values into a modern-day equivalent. The one used here calculates the value of the goods or service as a multiple of the average contemporary wage. So if the cost of a patent was ten times the annual income of an average worker in 1846, the modern value is calculated as the annual income of an average worker today, multiplied by ten. This is particularly useful in indicating the relative value of commodities in terms of labour. Officer and Williamson (2011).

28 The full cost reported by Poole for a Scottish patent was $£ 7910 \mathrm{~s}$. 5d, but this figure included other costs such as patent agency fees. To make the figure reported in the text comparable with the quote from the 1849 Committee these costs were excluded. House of Commons (1829, III:87).

29 House of Commons (1829, III:17). 
day), obtaining the Privy Seal Bill on the same day as when the Signet Bill was entered cost $£ 111 \mathrm{~s} .6 \mathrm{~d} .{ }^{30}$

The sheer variety of official fees, extra fees, specification fees and agency fees makes it very difficult to present an 'average' cost for an English, Scottish or Irish patent. Instead, it is more useful to think in terms of what would be the minimum cost of an enforceable patent. For an English patent, official fees (ignoring any extras) cost $£ 95$, agency fees ten guineas, specification fees (at a reasonable minimum) $£ 20$ and technical consultancy another $£ 20$. This brings the total cost to around $£ 145$. One expense that patentees in Scotland and Ireland would have been spared were the charges for legal and technical assistance for the preparation of the specification. As will be discussed later, Scottish and Irish patents usually had an English equivalent, which was normally sealed first. Because the same description could be entered for the different national patents, the professional fees in preparing the specification only had to be incurred on entering the first (English) specification. In Ireland then, a patent would have cost, at a minimum, $£ 145$ ( $£ 115$ for fees, $£ 10$ agency fees, $£ 20$ specification fees). In Scotland, the total (minimum) cost would have been $£ 90$, bringing the total cost for an 1849 'British' patent to $£ 380$ or around $£ 270,000$ in 2013 prices.

This presents an opportunity. Because the petition procedure, and its attendant costs, were relatively uniform, it is possible to regard individual English, Scottish and Irish patents as equivalent statistical units. Before seeking to establish direct comparisons between the three countries, however, it is important to consider possible differences in patent law. There are two halves to this problem. Firstly, it is important that legal issues of authorship, novelty and patentability were adjudicated in the same manner by the three nation's courts. If, for example, novelty requirements were less rigorously enforced in Ireland than in Scotland, there would be more patents in Ireland than if Scottish standards of novelty were maintained. The second half relates to the problem of the legal status of a patent or invention in another part of the United Kingdom. In particular, was it possible for a party to circumvent a patent in one part of the Union by importing and selling the protected article from another, where no patent was in force?

Evidence regarding the first problem appears to be straightforward: the Scottish and Irish law reports clearly indicate that English patent law was considered to be authoritative, even in cases where it might conflict with Scottish and Irish law. ${ }^{31}$ In Templeton v MacFarlane (1848), for example, it was established over the course of the trial that part of the invention patented by Templeton was not novel. When summing up, Lord MacKenzie, one of the judges of the Court of Session, noted that 'if the first process was well known and used before, the patent is not good. If the matter rested on Scots law, we might apply the principle, utile per inutile non vitiatur; but we must go to the English rule, that if the patent is taken out for too much, it cannot stand'. ${ }^{32}$ The other judges consented, Lord Jeffrey observing that although he felt 'very considerable regret in concurring in the opinions last delivered, it is beyond doubt that, according to the rule of the law of England, which in cases of this nature we are bound to recognise, the whole patent must fall'. ${ }^{33}$ Concerning Ireland, although the

30 Hindmarch (1846, 612-14).

31 And the same point is made by Hector MacQueen: 'the law was essentially a unity north and south of the border'. MacQueen $(2010,25)$.

32 Which roughly translates to: 'the useful is not vitiated by the useless'. Hayward (1988, 5:884).

33 Hayward (1988, 5:887). 
records for patent cases are sparse, no material difference between Irish and English patent law appears. ${ }^{34}$

Evidence regarding the legal status of a patent or invention in another part of the United Kingdom is more problematic. The ambiguous wording of the patent raised the spectre of 'legal' infringement. While the part of the patent reciting the actual grant conferred the right to 'vend' the invention, the prohibitory part of the patent (that part which detailed the exclusion operating on other parties) made no mention of vending. This could be interpreted as permitting the manufacture or use of an invention in one part of the United Kingdom where a patent was not in force, and then selling (vending) it in another part where the patent was in force. It was, however, expressly decided in Universities of Oxford and Cambridge v Richardson (1803), that where a (copyright) patent was in force in England but not Ireland, 'if any of the King's subjects buy an article in Ireland, he cannot bring it here, where there is a patent for it, for the purpose of trading'. ${ }^{35}$ This decision was assimilated into the law of patents for inventions and was cited in contemporary patent treatises. For process inventions, however, where the end product was generic, the law was different. For example, in sugar-refining it was possible for an Irish refiner to freely adopt improvements as long as they had not been patented in Ireland. ${ }^{36}$ Further, they could then sell their refined sugar at a cost advantage in England where refiners did have to pay the licence fees.

This section has established the close similarities between the English, Scottish and Irish patent systems. Although theoretically autonomous, there was considerable uniformity in the petition procedure across the three countries. This uniformity extended to patent law as well, although there were some inconsistencies in the adjudication of patents from another country in the Union. The next section will describe the compilation of the English, Scottish and Irish patent series.

\section{Compiling the Scottish and Irish patent series}

After the Patent Law Amendment Act, the first Superintendent of Specifications (Bennet Woodcroft) organised the cataloguing of all pre-reform English patents into four indices, the Chronological Index, the Alphabetical Index, the Subject Index and the Reference Index. ${ }^{37}$ These indices contain the same population of patents (i.e. all those awarded between 1617 and 30 September 1852), but each is organised differently, providing data supplementary to the others. Together, these four indices provide information on patent date, subject matter, patentee name, residency and references to the patent in contemporary technical literature. Since their publication, they have become the standard reference for pre-reform English patents.

\footnotetext{
34 See, for example, Baxter v Combe (1850), where the Irish Master of the Rolls, Sir Thomas Cusack-Smith, withheld an injunction because this was consistent with practice in England. Roberts and Shirley (1852-67, 1:285). In total, there were only 3 patent cases reported in Ireland before 1852 compared with 22 in Scotland and 389 in England. Legal action was expensive, $£ 600$ was the reported average for both sides, and it was only worth pursuing a case to trial if the patent right was a valuable one. The fact that there were many more cases in Scotland than in Ireland, indicates that patent rights tended to be more valuable there, and this tallies with their respective levels of economic development. Following this logic, it would also mean that the relative importance of a patent system for economic and technological activity can be proxied by counting the number of court cases it generated; the (approximate) ratio of (reported) cases from 1800 until 1852 for England, Scotland and Ireland of 300:30:3 is probably a fair reflection of the relative importance of patenting in each country.

35 Holroyd $(1830,177)$.

36 House of Lords (1851, XVIII:149).

37 Nuvolari and Tartari $(2011,109)$.
} 
Although there is no Scottish or Irish equivalent to these indices, for both there survive hand-written lists in the British Library. These lists provide some of the information to be found for English patents, listing patentee name, date of grant and subject matter. Although it is possible that these lists were compiled as part of the same cataloguing effort that produced the four Woodcroft indices, there is no evidence to support this supposition. Neither do they appear on the British Library (BL) Integrated Catalogue. ${ }^{38}$ Consequently, it was important to verify the reliability of these lists. In the case of Scotland, the BL list was checked with the Great Seal Register, held at the National Archives of Scotland in Edinburgh. Whenever a patent was sealed in Scotland (at the fifth stage of the petition), it was recorded in the Great Seal Register and as such, this can be regarded as the definitive record. ${ }^{39}$ In general, the BL list is fairly reliable, except for the eighteenth century where it lists only 81 patents, whereas the Great Seal Register records 163 and the BL list has been supplemented with these additional patents. In total, the BL list provides 3777 patents between 1700 and 1852 , the Great Seal Register 4035.

The BL list for Ireland is also incomplete. Firstly, it only lists patents for which specifications were entered. This leads to an underestimate of the total number of patents granted in Ireland vis-à-vis Scotland and England, where all patents to have received the Seal are counted. Secondly, as with Scotland, it appears to undercount the number of patents awarded during the eighteenth century, listing only 7 . Fortunately, there is a contemporary Home Office document (derived from the original patent rolls) listing Irish patents for invention from before $1827 .^{40}$ This lists 62 Irish patents for the eighteenth century (and reassuringly, all 7 patents listed in the BL list appear in the Home Office paper). Because it includes all patents (unspecified as well as specified), the Home Office list has been used as the main source for pre-1827 Irish patents for inventions. After 1826, only the BL list is available.

It is possible to estimate how many patents are excluded from the BL list after 1826 by comparing it with the Home Office paper. Of 350 patents listed between 1800 and 1826 in the Home Office paper, 322 appear in the specification index. This means 28 patents were awarded for which no specification was later entered, approximately 8.7 percent of the specification total. If we assume this proportion of unspecified to specified patents was the same between 1827 and 1852, then a total number of specified patents of 1169 implies there were around 1275 patents awarded in total. ${ }^{41}$ Although this only represents a small underestimate, ideally, it would have been possible to use the original Irish patent rolls for a check similar to the one undertaken with the Great Seal Register for Scotland. Unfortunately, the Irish patent rolls were destroyed during the AngloIrish War in 1921.

After collecting the data, Irish and Scottish patents were matched with their English equivalents.

38 The two indices are obtainable by asking at the Intellectual Property desk in the British Library. Their titles are Irish index to specifications, 1788-1855 and Scottish index to patents, 1767-1853. For further details, see references.

39 C3. Great Seal Register (Registrum Magni Sigilli) Paper Register, 1608-2008.

40 HO. Return to Parliament from the Rolls Office of the titles and dates of patents granted in Ireland for manufactures and inventions, 1700-1826.

41 The proportion of unspecified Irish patents was probably smaller than this in the second quarter of the nineteenth century, largely because so few English patents were unspecified (5.4 percent) before 1852 and they were normally obtained before their Irish counterparts. Andrew, MacLeod, Stein, Tann $(2003,556)$. 
Generally, Scottish and/or Irish patents were obtained under the same name, similar patent title and (due to the specification requirement) within six months of the English patent. This made the large majority of matches straightforward. ${ }^{42}$ For instance, the English patent granted to Thomas Dunn for a 'Turntable to be used on railways', on the $13^{\text {th }}$ March 1845, (English patent no. 10556) was matched with the Scottish patent granted to Thomas Dunn for 'Certain improvements in or applicable to turn tables to be used on or in connection with Railway', on the $4^{\text {th }}$ April 1845 and with the Irish specification entered by Thomas Dunn for 'turntables for railways' on the $19^{\text {th }}$ November $1845 .{ }^{43}$

There were a minority of cases where there was some ambiguity in the match. For example, the Irish patent granted to Benjamin Batley for a 'New method of curing and preserving herrings' on the $15^{\text {th }}$ November 1800 could have been matched with either the English patent granted to Benjamin Batley on the $11^{\text {th }}$ September 1800 (no.2441) for 'Curing and preserving herrings and sprats', or with the patent awarded to him on the $25^{\text {th }}$ January 1801 (no.2465) for 'Curing and preserving herrings, sprats, and other fish'. In this instance and in other cases of ambiguity, the match was made with the English patent with a date preceding the Scottish or Irish grant. This was because inventors tended to obtain English patents before an Irish or Scottish one, irrespective of residence. ${ }^{44}$

There were also cases where there was not an exact match in the information between the English patent and a Scottish or Irish patent, but where it was reasonable to suppose a match could be made. For example, an English patent awarded to James Mayer for a 'machine for cutting splints for matches' on the $4^{\text {th }}$ December 1839 (no.8297) was matched with an Irish specification entered by Antonio J Mayer for 'cutting splints for matches' on the $24^{\text {th }}$ September 1840.

There were also a small number of patents ( 3 in Ireland, 22 in Scotland) where no precise match could be made although it was likely that there was an English equivalent. This occurred where an individual was responsible for a number of patents with similar subjects in a short period of time. After matching there remained a few Scottish and Irish patents without a matching English patent, presumably because one was never obtained.

\section{Interpreting the Scottish and Irish patent series}

Section 2 examined the law and administration of patents in England, Scotland and Ireland. Because the costs and requirements of obtaining and enforcing patents were broadly the same, patents within the three jurisdictions may be regarded as statistically comparable i.e. that a Scottish patent is an equivalent statistical unit to an English or Irish patent. Section 3 outlined the compilation of the English, Scottish and Irish patent

42 For post-1826 Irish patents, the time limit for matches between English and Irish patents was increased to twelve months, because only the date of the Irish specification was recorded. The Irish specification could be entered twelve months after the English patent was dated because six months were allowed to enter the English specification (by which time the Irish patent had to be sealed) after which another six months were allowed to enter the Irish specification.

43 Note that this is the date the Irish specification was submitted, not when the Seal was attached to the patent. Assuming Dunn used the full six months available to him, the Irish patent would have been dated $19^{\text {th }}$ May 1846 .

44 For example, one prominent patent agent before the 1849 Parliamentary Select Committee, claimed that Scottish or Irish inventors 'almost invariably come or write to London first'. House of Commons (1849, XXII:30). 
series between which there is only one discrepancy - after 1826 the Irish series only lists patents with which a specification was submitted. Nonetheless, this discrepancy is minor and does not preclude a comparative analysis of the three patent series.

The first historian to analyse the English patent series during the Industrial Revolution was Richard Sullivan. He argues that the patent count indicates the level of resources committed to (patentable) inventive activity. ${ }^{45}$ Accordingly, he interprets an acceleration in the growth trend in English patents during the late 1750s as registering an acceleration in the growth of resources committed to inventive activity. ${ }^{46}$ This in turn is interpreted as marking the beginning of the Industrial Revolution. Sullivan's argument, however, assumes that the propensity to patent inventions was both high and invariant over time, implying an implausibly low level of inventive activity before 1750. The untenability of Sullivan's assumptions is confirmed in light of Petra Moser's quantitative work on the exhibits of the 1851 Great Exhibition. Moser established that a substantial proportion of exhibits were not patented and that the propensity to patent varied considerably across industries. ${ }^{47}$

This shows that patent numbers cannot be interpreted as a straightforward measure of inventiveness. This is not to suggest that the growth in English patent numbers is entirely divorced from changes in the extent of inventive activity, but that inventive activity is not the only factor to influence changes in patent numbers. Rather, there are other factors that influence the propensity to patent. Christine MacLeod attributes the increase in patenting activity during the 1750 s to a variety of economic factors. ${ }^{48}$ In particular, she suggests that increasing investment in capital equipment led to the development of a specialist capital goods sector. As the output of the sector grew so too did their return from acquiring patent protection. Similarly, increasing disposable incomes also led to more 'consumer' patents. These developments contributed to the development of a 'first-strike mentality' among inventors; it was now necessary to patent improvements defensively, to preempt competitors from doing the same. Although this argument is rather hotchpotch, there is one underlying claim: that changes in the economy made patent protection more valuable.

Finally, institutional reform can also affect the number of patents awarded. When the Patent Law Amendment Act was passed in 1852, it dissolved the separate English, Scottish and Irish patent administrations and introduced a single British patent, on which the fees were reduced. Patents could now be obtained at an initial cost of $£ 25$, followed by $£ 50$ after three years and $£ 100$ after seven. Because an inventor could secure patent protection for the whole of the United Kingdom at a much lower cost there was a massive increase in the number of patents awarded. In 1851, the last full year before reform, 455 patents were awarded in England. ${ }^{49}$ In 1853 , there were 2187 patents awarded in the United Kingdom. ${ }^{50}$

Patent numbers then are a 'messy' indicator, responsive to changes in institutions, levels of

45 Sullivan $(1990,351)$.

46 Sullivan $(1989,425)$.

47 Moser $(2007,37)$.

48 MacLeod (1988, 148-49).

49 Strictly speaking, this is not an accurate comparison because it excludes patents that were awarded in Scotland and Ireland but for which protection was not obtained for England. However, including these patents only adds 4 to the total for 1851. House of Commons (1851, XVIII:34).

50 Federico $(1964,113)$. 
inventiveness and the economy. In analysing the Scottish and Irish patent series, however, underlying levels of inventive activity can be factored out. This is because the large majority of inventions patented in Scotland and Ireland were not developed there. In Ireland, between 1800 and 1845, 84\% of first named patentees were resident in England, whereas only 6\% were from Ireland. The remainder were either from Scotland (7\%) or from abroad (3\%). Over the same period in Scotland, $87 \%$ of first named patentees came from England and only $10 \%$ from Scotland. Similarly, almost all inventions for which patents were obtained in Scotland and Ireland were also patented in England. From 1750 to 1851 there were only 166 Scottish patents that did not have an English counterpart, about 4\% of the total awarded. The comparable figure for Ireland was 66, again $\approx 4 \%$ of the total. Although in theory, the three populations might have been relatively independent, in practice it is more useful to think of Irish and Scottish patents as extensions to an original English patent.

Concerning the importance of changes to the accessibility of patent protection, perhaps the most significant development was the introduction of patent agency in the third quarter of the eighteenth century. There was also a sustained expansion and elucidation of patent law from the second half of the eighteenth century onwards. ${ }^{51}$ These developments would have increased the propensity to patent. There is, however, no reason to suppose that it should have affected the relative propensity to patent between the three countries. This is because these improvements also occurred in Ireland and Scotland. For example, the ready adoption of English patent law in Scotland and Ireland means that there was not a significant divergence in the patent law of the three countries. By process of elimination, this means that relative changes in the number of patents in Scotland and Ireland should be attributable to changes in the economic opportunity of protecting industrial technology. This inference is supported by modern data. Nicolas van Zeebroeck and Bruno van Pottelsberghe have established that there is a strong correlation between the number of patents filed in the European Patent Office for a particular country and the size of that country's GDP. ${ }^{52}$

There are three factors that would have influenced a party's decision to extend a patent to Scotland or Ireland (besides affordability). The first of these was the perceived 'quality' of the invention. Generally speaking, the more valuable the invention, the more extensive the protection the inventor would invest in. Secondly, the decision to extend a patent would be influenced by the size and the value of the market for the invention in that particular country. Economic growth would augment the expected market for inventions and so would be expected to lead to an increase in patenting. Thirdly, the decision to extend a patent would be influenced by the extent of an individual's personal and business connections in that country. This third factor probably increased in importance with improving communications and market integration between the three countries although these developments were themselves bound up with changes in the economy.

There is, potentially, a fourth factor that was mentioned at the end of the first section. It may have been that patentees with process inventions obtained Scottish and Irish patents to secure their English patent against imports made using their invention from these countries. However, it is unlikely that this was an important factor. Firstly, there is no direct evidence to suggest that this was ever a consideration for an inventor extending their patent to Scotland or Ireland. Secondly, it would only be worthwhile going to the expense of say, patenting

51 Bottomley (2014). This contradicts previous arguments made by Dutton (1984) and MacLeod (1988).

52 Van Pottelsberghe de la Potterie and Van Zeebroeck $(2008,324)$. 
an improvement in sugar refining in Ireland, if there was an Irish sugar-refining industry that was able to compete with the English one. If this was the case, then it was probably worth getting the patent anyway for the more straightforward reason of exploiting it oneself. Consequently, it is likely that Scottish and Irish patents do denote the opportunity of patenting technology in those countries.

The reasoning behind these first three factors is used in 'family size analysis' to appraise the value of patented inventions. Van Zeebroeck summarises the rationale for this analysis as follows: 'given the costs required to file and enforce patents in multiple countries, only those with sufficient expected value to their owners will be extended abroad', that in effect patent value can be inferred from the number of jurisdictions in which patent protection is obtained.$^{53}$ In a test of various methods of estimating patent value against a dataset where value assessments had come directly from a survey of the patent holders, Harhoff, Scherer and Vopel found that 'family size, the number of jurisdictions for which patent protection was granted carries the expected positive sign and is highly significant' in relation to the patent's empirical value. ${ }^{54}$ Van Zeebroeck also notes that family size analysis can be used to 'denote an expected market for the patented technology', i.e. that an analysis of the distribution of patents between industries can isolate the relative opportunities for new technologies in different countries. ${ }^{55}$ This facet of family size analysis will be explored in the rest of this section with reference to Scotland and Ireland. However, to attribute differences in their respective patent series to changes in their economy, it is necessary to outline a brief chronology of industrial development in Scotland and Ireland.

In the first half of the nineteenth century, Ireland was probably the poorest country in Western Europe - tragically evidenced by the Great Famine at the end of the 1840s. Even before then, however, had been falling throughout Ireland.$^{56}$ Irish manufacturing was also declining, although whether this was a relative or absolute decline is the matter of some debate. Peter Solar argues that with the abolition of duties on Anglo-Irish trade in the $1820 \mathrm{~s}$, most Irish industries struggled to compete and began to disappear. ${ }^{57}$ Cormac Ó Gráda also notes that by 1830, Ireland had abandoned (energy-hungry) industries such as glass-making, sugar-refining and salt production, but attributes this to high coal prices.$^{58}$ Frank Geary provides a slightly more positive assessment of Irish industrial performance, noting that Irish manufactured exports to Britain were growing over the first quarter of the nineteenth century. ${ }^{59}$ Thereafter, however, Geary's figures reveal that a declining proportion of the Irish labour force was engaged in manufacturing or trade. At the 1821 census, $41.2 \%$ of the Irish labour force was recorded in manufacturing and trade. Twenty years later this figure had fallen to $33.6 \%$ and in the 1840 s, to compound the misery inflicted by the famine, another 400,000 jobs were lost in textiles alone.$^{60}$ It is clear then that the proportion of the Irish labour-force involved in manufacturing was falling during the nineteenth century, although with technological developments labour productivity would have been improving.




Consequently, there probably was some growth in aggregate output. ${ }^{61}$

The economic history of Scotland is as remarkable as that of Ireland albeit for very different reasons. By 1851, Scotland had experienced a process of industrialisation that had wrought changes every bit as transformative as anything that had happened in England. ${ }^{62}$ In the eighteenth century, Scotland was relatively poor. In 1765 and 1795, carpenters' wages in Aberdeen, Glasgow and Edinburgh were consistently less than two-thirds of what their counterparts in Manchester were earning - and they in turn earned much less than a carpenter in London. ${ }^{63}$ In the last quarter of the century though, the Scottish textile industry began to expand with annual imports of cotton growing seventeen fold between 1781-86 and 1799-1804 ${ }^{64}$ Textiles dominated large scale manufacturing during the first quarter of the nineteenth century, but after 1830, there was an abrupt diversification of Scottish manufacturing into other 'revolutionary' sectors. ${ }^{65}$ Especially important was Neilson's invention of the hot blast process. This allowed the use of both native black band ironstone and raw coal in iron manufacture and consequently, Scottish iron output grew from 37,500 tons in 1830 to 700,000 tons twenty years later. ${ }^{66}$ With access to the cheapest iron in the world, Scottish industry diversified into railways, shipbuilding, engineering and mining. As early as 1841 , Crafts estimates that the proportion of male workers in 'revolutionised industry' was above $30 \%$ in 3 out of 8 Scottish regions compared to 4 out of 43 in England. ${ }^{67}$

Although this is only a brief overview of the relevant Scottish and Irish economic history, it is clear that the two countries experienced contrasting fortunes. While manufacturing in Ireland stagnated through to 1851, Scotland had already industrialised. This suggests that there should be divergent patterns in their respective patent series. Because Scotland's rapid industrial development made the protection of new inventions more valuable than in Ireland, we would expect to see many more patents in Scotland than Ireland. Figure 1 shows the number of patents awarded in England, Scotland and Ireland for every year between 1700 and 1851 (the last full year before the patent system was reformed). The light-coloured lines indicate the annual total of patents awarded in each of the three countries and is plotted on the left hand axis. There is considerable fluctuation in the annual totals and so to clarify the longer term trends, the total number of patents in force on 31 December is plotted on the right hand axis for each year (and this is simply calculated by adding up the number of patents awarded in the previous fourteen years).$^{68}$ These are shown by the darker lines.

\footnotetext{
61 Ó Gráda $(1994,308)$.

62 Whatley $(1997,7)$.

33 Hunt $(1986,964)$.

64 Whatley $(1997,7)$.

65 Devine $(2004,399)$.

66 Devine $(2004,400)$.

67 Crafts $(1985,4-5)$.

68 This does not take into account the very small number of patents that had their term extended.
} 


\section{Figure 1}

British patents, 1700-1851

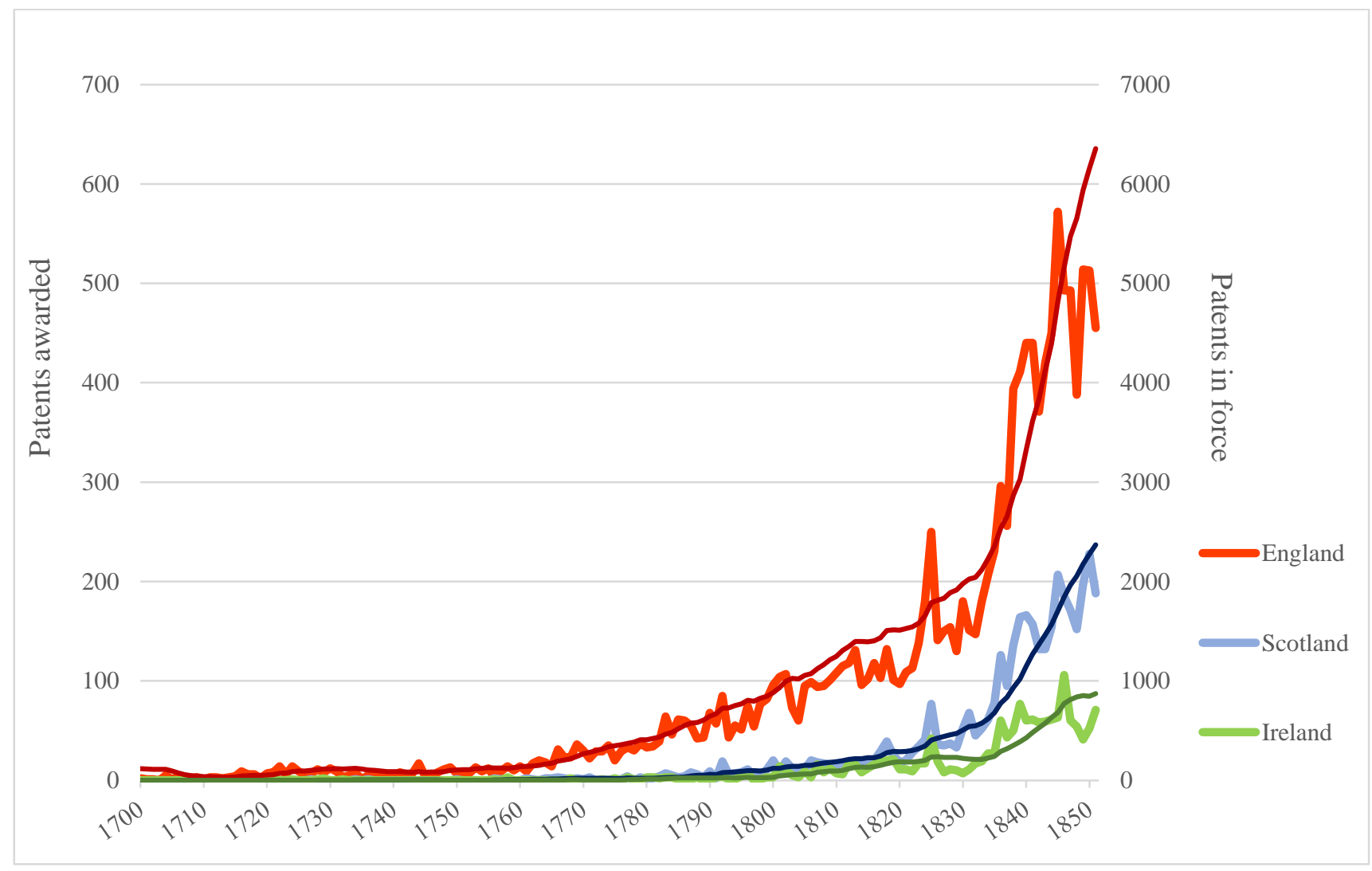

The overall growth in patenting is striking. Figure 1 shows that before 1760 very few patents were awarded anywhere in the United Kingdom - in 1750, there were only eight patents awarded, seven in England and one in Scotland - and there is no discernible pattern of growth. Thereafter, however, there is a steady acceleration in the growth of English patent numbers, and Richard Sullivan, plotting the growth in English patents on a logarithmic scale, isolated a break-point near the end of the $1750 \mathrm{~s} .{ }^{69}$ In 1800, 96 patents were awarded in England, in 1850, 513. This pattern is similar in Scotland and Ireland, albeit with a slightly different chronology. Annual patent totals in both countries remained close to zero until 1775 after which there was steady growth (1772 was the last year in which no patents were awarded in either Scotland or Ireland). One important difference between Scotland and Ireland is that after 1825 Scottish patent numbers continued to grow while in Ireland numbers remained low. From 1826 to 1851, there were almost three times as many Scottish patents (3087) than Irish (1132); in only one year did the number of patents awarded in Ireland reach three figures, 106 in 1846 - not far off the 109 awarded by the Free State a century later in 1946, a stark indicator of Ireland's persistent backwardness until quite late into the twentieth century. ${ }^{70}$ These long term

69 Sullivan $(1989,430)$.

70 This was admittedly the post-war nadir for patenting in Ireland, but excluding the two years after 1927 (when the Free State first instituted a patent system), it would not be until 1961, that the number of patents awarded per annum in Ireland would reach four figures. Of the 1084 patents awarded that year, only 86 were obtained by Irishmen; Britons accounted for 307 and Americans 221. Federico (1964, 123 \& 152). 
patterns become clearer when the number of patents in force for each year is also plotted. At the end of 1851, there were 2369 patents in force in Scotland, comparable to the 2365 patents in force in England at the end of 1835. In Ireland, by contrast, there were 873 patents in force at the end of 1851 - a figure that was reached in England in 1799.

As discussed above, the large majority of Scottish and Irish patents can be regarded as extensions of an original English patent. Figure 1 clearly indicates Scotland's performance relative to Ireland, but it is also important to consider the extent to which growth in Scottish and Irish patenting was driven by growth in the 'base' English series. If the propensity to extend patent protection to Scotland remained constant, this would imply that there was no Scottish industrial 'catch-up'. Figure 2 shows the number of patents in force in Scotland and Ireland, as a percentage of the number of patents in force in England from 1775 to 1851.

\section{Figure 2}

Patents in force in Scotland and Ireland as a percentage of patents in force in England, 1775-1851

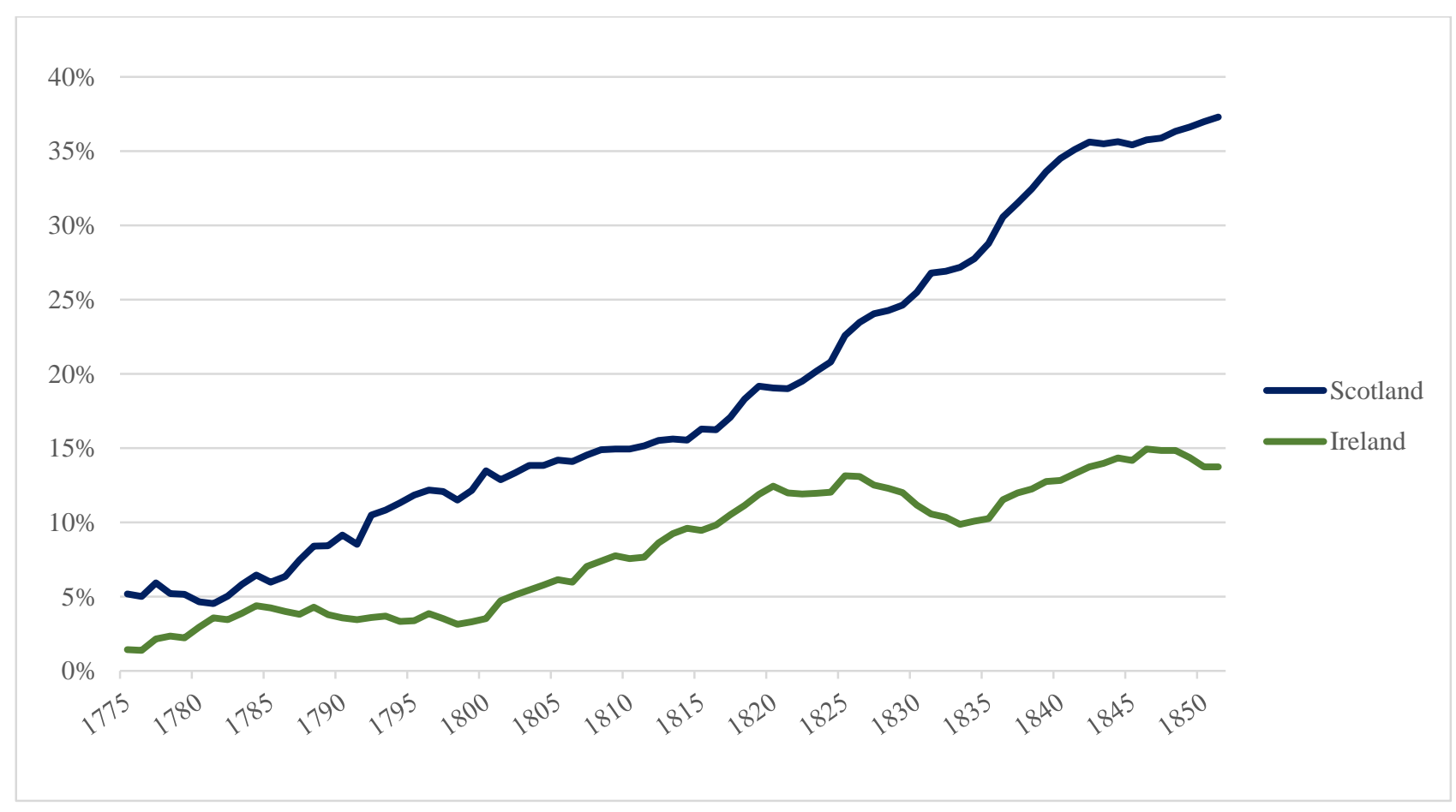

In 1775, relative to England, very few patents were in force in Scotland and/or Ireland. However, the number of patents in Scotland, relative to England, grows consistently throughout the period - most dramatically during Scottish industrialisation in the 1830s. In 1828 (the year when Neilson's hot blast process was patented), the number of patents in force was already $24.3 \%$ of the English total but in the space of a single fourteen year patent term, this figure had reached $35.6 \%$. This is especially impressive in light of the rapid growth of English patenting over the same period, shown in Figure 1. Concerning Ireland, changes in this series closely match changes in the Anglo-Irish political/economic relationship. Of particular note, considering the on-going debate over its economic consequences, is that the number of patents in force in Ireland remains 
extremely low until the Union in 1801 - just 3.5\% of the English total in $1800 .{ }^{71}$ Inventors rarely perceived any value in extending patent protection to Ireland. Thereafter, there is some growth, so that this figure reaches $13.1 \%$ in 1825 . The 1820s, however, saw the gradual abolition of all Anglo-Irish trade duties, a process that was eventually finished in 1826, the same year as when the Irish pound and pound sterling were amalgamated. Solar, amongst others, has argued that the subsequent competition from Britain eviscerated Irish industry and evidence from the patent series supports this. After 1825, the modest growth trend seen in the first quarter of the nineteenth century ends abruptly and before the unification of the three patent systems in 1852, Irish patents in force as a percentage of English patents never reaches 15\%.

The difference between Scotland and Ireland becomes even starker when looking at per capita patenting. Table 1 presents the number of patents in force per million population for every census year between 1801 and 1851, as well as 1781 (and 1791), the earliest year for which reliable population data is available.

\section{Table 1}

Scottish and Irish Patents by population, 1781-1851

$\begin{array}{crrr}\text { Ireland } & & & \\ \text { Year } & \text { Population }^{\mathrm{a}} & \text { Patents in force } & \text { Patents in force per million population } \\ 1781 & 4.05 & 15 & 3.7 \\ 1791 & 4.75 & 23 & 4.8 \\ 1801 & 5.22 & 44 & 8.4 \\ 1811 & 5.96 & 100 & 16.8 \\ 1821 & 6.80 & 183 & 26.9 \\ 1831 & 7.77 & 214 & 27.6 \\ 1841 & 8.20 & 480 & 58.5 \\ 1851 & 6.51 & 873 & 134.0 \\ & & & \\ \text { Scot- } & & & \\ \text { land } & & & \\ \text { Year } & \text { Population } & 19 & 13.0 \\ 1781 & \approx 1.46 & 57 & 37.0 \\ 1791 & \approx 1.54 & 120 & 73.8 \\ 1801 & 1.63 & 198 & 108.6 \\ 1811 & 1.82 & 290 & 138.1 \\ 1821 & 2.10 & 543 & 228.7 \\ 1831 & 2.37 & 1270 & 484.4 \\ 1841 & 2.62 & 2369 & 818.0 \\ 1851 & 2.90 & & \end{array}$


assuming a constant rate of growth between 1755 (the year of Reverend Alexander Webster's survey) and the first census in 1801 .

71 See, for example, Geary (1995) 
Table 1 confirms the disparity between the two countries, but also shows that Scotland had held a considerable lead (in per capita terms) over Ireland since 1781, long before it industrialized. It may be that Scotland was already a more promising place for inventors to pursue returns from new technology. Scotland maintained this lead into the nineteenth century. By 1811, there were over 100 patents in force in Scotland per million population, over six times the Irish figure (16.8). In 1851, again, there were over six times as many patents in force per million population in Scotland (818) than in Ireland (134).

These results were anticipated by the discussion of patent family analysis and the comparative industrial performance of Scotland and Ireland. In the 1820s, 30s and 40s, the number of patents in force per million population doubled in each decade. The same could be said of Ireland (with the exception of the 1820s), but this growth occurred from a much lower starting point and was driven by the largely exogenous increase in English patenting. The growth trend in patenting in the two countries strongly supports the contention that inventors were responding to the relative economic opportunity of protecting their inventions in various jurisdictions. For this argument to be robust, however, this pattern also needs to be demonstrated at the sectoral level. In particular, Crafts' work on the share of Scottish and English adult male labour in 'revolutionary' industrial sectors suggests that patenting in Scotland should have been more heavily concentrated in those sectors compared with England and Ireland. ${ }^{72}$

Table 2 provides the sectoral distribution of patents awarded in England, Scotland and Ireland. It uses the same sectoral classification as used by Nuvolari and Tartari in their 2011 paper, which classified all English patents awarded until $1841 .^{73}$ Because they have not been classified, Table 2 omits inventions that were only patented in Scotland and/or Ireland, as well as all patents sealed after 1841. The first row for each country shows the total number of patents awarded in each sector between 1775 and 1841 . The second row gives the percentage of all patents accounted for by that sector. The third row gives the concentration statistic for each sector, the fraction of patents in that sector squared. At the bottom of the third row is the sum of the concentration statistics, the Herfindahl Index. Finally, below this, is a figure showing 1 divided by the Herfindahl Index. This equates to the number of sectors there would need to be for there to be an equal distribution between them, as denoted by the Herfindahl Index. So if there were an equal distribution between the 21 sectors, the Herfindahl Index would be $0.0476(1 / 21)$. This figure represents a measure of how sectorally concentrated the patent population was, with a higher value denoting a more equal distribution.

72 Although the work of Moser, discussed above, emphasises the difficulties in using patent statistics to analyse the sectoral distribution of inventive activity the concern here is the relative sectoral distribution of patents between the three countries.

73 Nuvolari and Tartari $(2011,112)$. 


\section{Table 2}

Sectoral concentration of British patents, 1775-1841

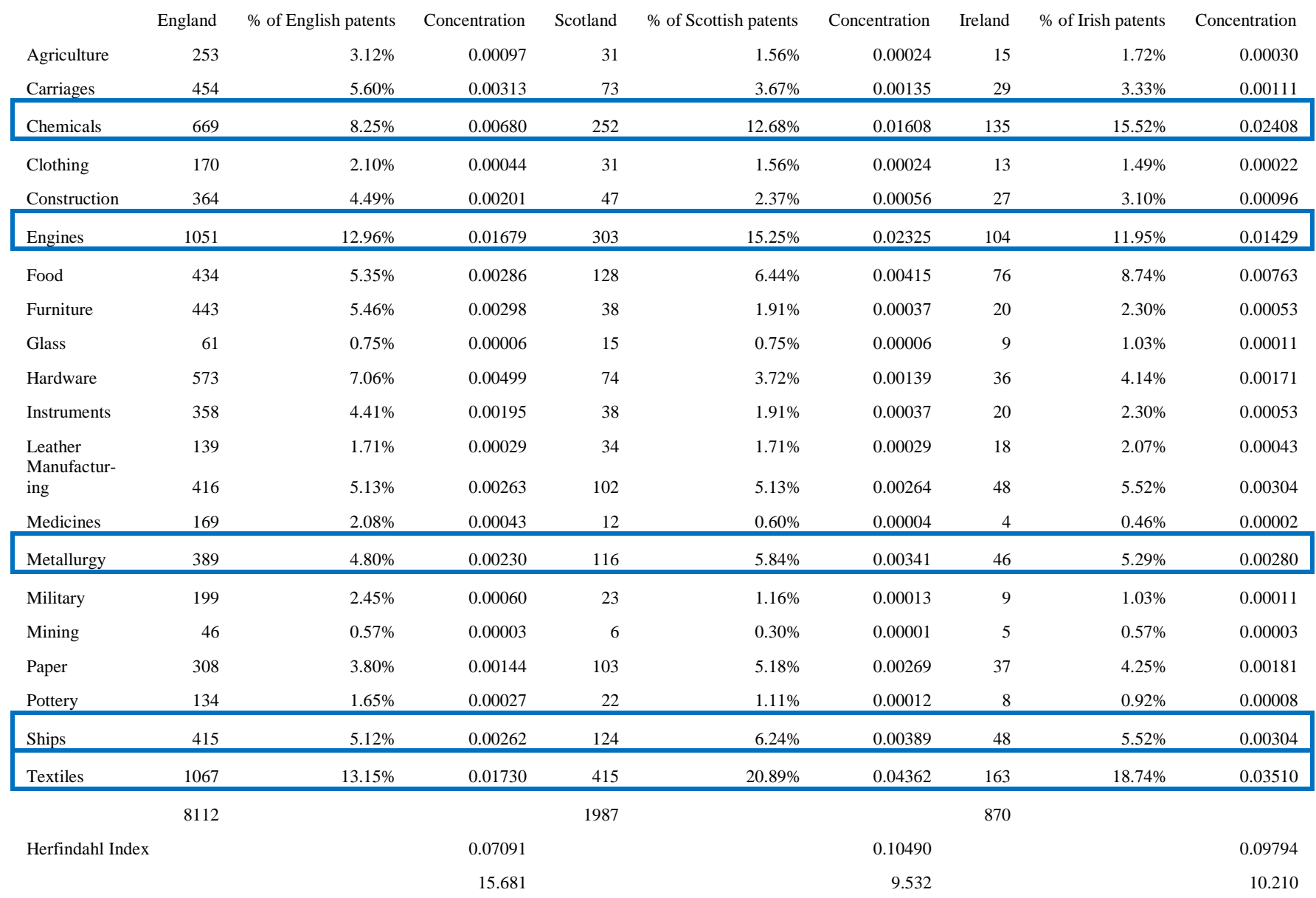

Scottish patents have a much higher Herfindahl index score ( 0.105 or 9.53 sector equivalent) than English patents ( 0.063 or 15.68 sector equivalent). The difference with Irish patents ( 0.098 or 10.21 sector equivalent), appears to be less pronounced, although this can be explained in the following section. In which sectors were Scottish patents concentrated? The fore-going discussion has suggested that Scottish patents would be predominately found in heavy 'revolutionised' industry. For comparison Crafts' definition of revolutionised industry, referred to earlier, is adopted. Crafts' figures for employment in 'revolutionised industry', used Clive Lee's employment categories, of chemicals, metal manufacture, engineering, vehicles, textiles and transport. ${ }^{74}$ Although the sectoral classification used by Lee (and Crafts) differs from that used to classify these patents, here 'revolutionised' industries are taken as chemicals, metallurgy, engines, textiles and ships. These sectors are highlighted with a blue border. It can be seen that in Scotland four of these five sectors (engines, metallurgy, ships and textiles), accounted for a higher proportion of patents than in England or Ireland populations. Similarly, the fifth sector (chemicals) accounted for a higher share of patents in Scotland than in England. The combined share of these 'revolutionary' patents was $61 \%$ in Scotland compared with $42 \%$ in

74 Crafts $(1985,5)$. 
England (and 57\% in Ireland): Scottish patents were concentrated in heavy industry.

This section began by outlining some of the problems and ambiguities involved with interpreting patent numbers. It was argued, however, that because the large majority of patented inventions in Scotland and Ireland originated from England, their patent series could be plausibly interpreted as denoting the market for new inventions. An analysis of the Irish and Scottish patent series, at the aggregate and sectoral level, has been shown to tally with their respective industrial performances, implying that inventors were responsive to economic and commercial opportunities. This contention will be explored further in the final section.

\section{Invention and the market}

The results in the previous section indicate that inventors made informed decisions on the commercial value of extending patent protection to Scotland and/or Ireland. More generally, this would indicate that inventors were responsive to market signals in their activities. Tom Nicholas, using patent renewal and historical citations data, makes a similar case regarding British invention between 1880 and 1930, arguing that inventors 'were responding to expected profits' in their inventive activity. ${ }^{75}$ Although the British economy (and patent system) was more developed at this later point, it did share some important characteristics with the period under consideration here. In particular, invention was dominated by independent inventors and there was a developed market in assigning and licensing patent rights. ${ }^{76}$

Section 2 discussed how the costs of patent protection increased with the number of countries in which it was acquired. The cost of a patent for England was £145, for England and Scotland, $£ 235$ and all three countries, $£ 380$. In addition, because there may be more infringements to police and prosecute, the costs of enforcing a patent also increase with geographical scope. Because of these additional costs, if patentees were responsive to market forces, it would be expected that those inventions of a lower prospective value would not be extended to Scotland and/or Ireland. This proposition can be tested using Alessandro Nuvolari and Valentina Tartari's WRI* (Woodcroft Reference Index) indicator of patent quality. As discussed at the beginning of section 3, the pre-reform English patent catalogue, was organised into four indices. One, the Reference Index, provided references to the patent in the contemporary technical and legal literature. Nuvolari and Tartari use the number of references each patent garnered as an indicator of its technical quality. The lowest WRI figure is zero, where the Index only provided the office in which the specification was lodged. ${ }^{77}$ The highest raw value was 23 for a patent awarded to Cornelius Whitehouse for manufacturing gas tubes in 1825 . However, the average number of references received by patents increased over time. To control for this, the WRI score of each patent was adjusted by dividing it by the average number of references received by patents in the same time cohort, producing a time-adjusted score (WRI*). ${ }^{78}$ The patent with the highest WRI* score was James Watt's 1769 patent for the separate condenser (26.17).

Nuvolari and Tartari tested the reliability of the WRI* indicator by comparing the quality of four

75 Nicholas $(2011,1015)$.

76 On the market in patent rights before 1852, see Bottomley (2014).

77 Nuvolari and Tartari $(2011,103)$.

78 These time cohorts were 1617-1701, 1702-21, 1722-41, 1742-61, 1762-81, 1782-1801, 1802-11, 1812-21, 182231 and 1832-41. Nuvolari and Tartari $(2011,103)$. 
populations of 'important patents', as defined elsewhere in the historiography, with all other patents awarded between 1700 and 1841. They found that in all cases relating to the four populations of important patents, the hypothesis of stochastic equality could be rejected at the significance level of $1 \% .{ }^{79}$ This means that the WRI* indicator may be regarded as a robust indicator of the technical quality of an invention.

Nuvolari and Tartari allotted all English patents awarded between 1700 and 1841 a WRI* score. Because Scottish and Irish matches had already been established with English patents, it was possible to measure and compare the $\mathrm{WRI}^{*}$ score of those patents where protection was only obtained in England ('popE'), the scores of those English patents where protection was extended to Scotland ('popES') and where protection was extended to Scotland and Ireland ('popESI'). The first half of Table 3 compares the quality of these three populations for the periods 1775 to 1841,1775 to 1827 (roughly coterminous with the 'classical' Industrial Revolution in England and before there was rapid growth in the Scottish patent series) and 1828 to 1841 . The second half repeats the exercise using only those patents that were classified as 'industrial' in Table 2. The table reports the Mann-Whitney statistic for each of the eighteen comparisons, a non-parametric test of the null hypothesis that the (WRI*) value of the various populations are the same.

\section{Table 3}

British patent quality, 1775-1841

All Patents (1775-1841)

England (popE)

England \& Scotland (popES)

England, Scotland \& Ireland (popESI)

popE $\mathrm{v}$ popES

popE $\mathrm{v}$ popESI

popES $\mathrm{v}$ popESI

\section{5-1827}

popE

popES

popESI

popE $\mathrm{v}$ popES

popE $\mathrm{v}$ popESI

popES $\mathrm{v}$ popESI

\section{8-1841}

popE

popES

popESI

popE $\mathrm{v}$ popES

popE $\mathrm{v}$ popESI

popES v popESI

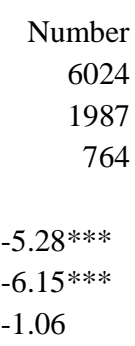

3686

760

328

$-5.60 * * *$

$-4.70 * * *$

$-0.79$

'Industrial' Patents
popE
popES
popESI

popE v popES

popE $\mathrm{v}$ popESI

popES $\mathrm{v}$ popESI

popE

popES

popESI

popE v popES

popE $\mathrm{v}$ popESI

popES $\mathrm{v}$ popESI

0.961

1.134

1.221

$-5.28 * * *$

$-4.41 * * *$

$-0.72$
popE

popES

popESI

popE v popES

popE v popESI

popES v popESI

$\begin{array}{rr}\text { Number } & \text { Mean WRI* } \\ 2336 & 0.951 \\ 1210 & 1.186 \\ 446 & 1.207\end{array}$

$-5.55 * * *$

$-4.13 * * *$

$-0.25$

$\begin{array}{rr}1304 & 0.985 \\ 443 & 1.292 \\ 173 & 1.200\end{array}$

$-3.83 * * *$

$-2.25 * *$

0.31

1032

0.907

767

1.125

1.211

$*, * *, * * *$ indicates significance levels of $5 \%, 2 \%, 1 \%$.

79 Nuvolari and Tartari $(2011,105)$. 
Table 3 shows that for 1775-1841, the hypothesis of parity of quality between popE and popES can be rejected as a significance level of $1 \%$ - i.e. that the population of English patents which were extended into Scotland was of a higher quality than those which were not. This is also the case when looking just at those patents awarded in 1775-1827 (roughly the period of the Industrial Revolution in England) and those patents awarded in 1828-1841. Similarly, the hypothesis of parity of quality between popE and popESI can also be rejected at a significance level of $1 \%$ for all three periods. ${ }^{80}$ In the comparisons between popES and popESI, although the former has a consistently lower mean WRI*, and there appears to be a greater chance that a patent randomly chosen from popESI will have a larger WRI* score than a patent from popES, the result is not significant at the $5 \%$ level. ${ }^{81}$ The higher the value of the patented invention, the more likely it was to be extended into Scotland and/or Ireland. This also explains why Ireland had a heavier concentration of industrial patents than England ( $57 \%$ as opposed to $42 \%$ ) - as Nuvolari and Tartari show, high quality patents were concentrated in precisely these sectors. ${ }^{82}$ When looking just at industrial patents, the same patterns emerge. It might be expected that that as the propensity to extend protection for industrial patents into Scotland increased, so the difference in quality between popE and popES might disappear. However, the quality of the 'residual' of unextended English patents also declines (as shown by the fall in mean WRI* of these patents over the two periods), meaning that the difference in quality is maintained..$^{83}$

Another way of testing the relationship between patenting and the market, is to look at the correlation between fluctuations in the business cycle and short term movements in the patent series. As business conditions improve, the expected return to an invention will increase. This should lead to an increase in patenting for at least two reasons. Firstly, inventions that were not worth incurring the costs of obtaining a patent for, will now be valuable enough to protect. Secondly, the resources committed to developing an invention will increase in line with its prospective value, i.e. overall inventive activity should increase ${ }^{84}$ Either way, an increase in patenting when business conditions improve would indicate that inventors were responsive to market signals.

80 As an aside, these results also indicate that inventors were capable of objectively appraising the value of their invention and acting accordingly. As Thomas Åstebro (2003) has shown, this is not always the case. In this instance, though, it is likely that the expense of obtaining patent protection in Scotland and Ireland forced most inventors to be realistic about their chances of success (not that this prevented some from patenting perpetual motion devices)

81 And care should be taken not to attach too much significance to the average WRI* figures, especially for the smaller groups of patents. It is well known that the value of patents is skewed: that there are many patents with a very low value, and few with a very high value. When comparing the average WRI* value of industrial patents in popES and popESI for the period 1775-1827, it might appear that those patents in Ireland were of a lower value than those in Scotland. However, one of the patents in popES is James Watt's patent for the separate condenser (extended into Scotland in 1775 by Act of Parliament). If the Act had also extended the patent into Ireland instead of just Scotland, then their respective mean WRI* scores would have been 1.344 and 1.236 instead of 1.200 and 1.292. This illustrates the value of calculating the Mann-Whitney statistics, rather than just relying on mean WRI*. 82 Nuvolari and Tartari $(2011,110-13)$. This also means that the difference between Scotland and England is not as pronounced as it would appear from Table 2, but it is still significant that Scottish patents had a higher concentration of patents than the more restricted, higher quality, population of Irish patents

83 When the quality of popE industrial patents awarded between 1775-1827 is compared with those awarded between 1828-1841, the Mann-Whitney statistic is 1.55 (the former is of a higher quality) although this result only has a $p$-value of 0.061 .

84 Sokoloff $(1988,822)$. 
Data on the chronology of the business cycle is derived from Broadberry et al (2011). Broadberry presents two different chronologies. One is a stylised version of the 'classic' chronology of the business cycle, which was prepared by 'checking a large number of microeconomic time series and establishing turning points in "general business activity" as a "consensus of statistical data rather than turning-points in any particular magnitude such as national income" ${ }^{85}$ The second is Broadberry et al's own, and is obtained from changes in real GDP. For both chronologies, Broadberry has designated particular years as 'Peaks' or 'Troughs'. Not all years are included in this designation. Broadly speaking, the two chronologies coincide and the differences are attributed to the 'difficulties of assigning turning points on an annual basis when monthly data would be more appropriate'. ${ }^{86}$

For the patent series, it was necessary to isolate short term movements from the long-term upward trend. The number of patents awarded in every year was calculated as a proportion of all the patents awarded in a five year surrounding period. In Figure 1, for example, 1825 is clearly a peak year in the patent series - in total 327 patents were awarded in England and Scotland, a combined figure that would only be surpassed in 1836. Over the period 1823 to 1827,1082 patents were awarded, so the patent total for 1825 is rendered as 0.302 (327/1082). Irish patents have been excluded from this analysis because the business cycle chronologies also omit Ireland.

To test for the correlation between business conditions and fluctuations in the patent series, the Pearson product-moment correlation coefficient has been employed. The Pearson coefficient produces values from between -1 to +1 , where -1 indicates a perfect negative linear relationship, +1 a perfect negative linear relationship and 0 no linear relationship at all. Although much depends on context, in general any value over 0.5 (or under -0.5) is thought to denote a strong relationship, any value between 0.3 and 0.5 a relationship of moderate strength, 0.1 to 0.3 a weak relationship and anything between -0.09 and +0.09 is meaningless. The coefficient was calculated six times in all - for both the orthodox chronology and for Broadberry's new GDP derived chronology (and Table 4 uses Broadberry's own terminology to distinguish between the two), and for those years when there was a peak in the business cycle, for those years when there was a trough and for all other years (which are defined as 'normal').

\section{Table 4}

Correlation between the business cycle and the patent series, 1775-1849

\begin{tabular}{lrrr} 
& Peak & Trough & \multicolumn{1}{c}{ 'Normal' } \\
Sectoral indicator derived business cycle & 0.620 & -0.417 & -0.163 \\
GDP derived business cycle & 0.324 & -0.257 & 0.058
\end{tabular}

There are two reasons why these results will underestimate the 'true' strength of the relationship between the business cycle and patenting rates. Firstly, as mentioned by Broadberry, business conditions can change markedly within years. Doubtless, there are 'peak' years where for a number of months, 'normal' or 
even trough conditions prevailed. This will accordingly reinforce or dilute the raw patent count and so disrupt any correlation between the 'annual' business conditions and the patent count. Secondly, there may be some delay between business conditions, the decision to obtain the patent, and getting through the petition process to obtain the actual grant - although the petitioner could withdraw from the petition at any time (albeit at the cost of fees already paid), in response to changing business conditions. With this in mind, Table 4 clearly establishes the pro-cyclicality of patenting and market conditions. As would be expected, peak years are positively correlated with spikes in the patent series - although the result is much stronger when the orthodox chronology of business cycles is used rather than Broadberry's. Similarly, troughs in the business cycle are negatively correlated with patenting, although downturns are not as strongly related with patenting as is the exuberance of a boom.

\section{Conclusion}

Zorina Khan and Kenneth Sokoloff propose three conditions that need to hold for inventive activity to be deemed 'entrepreneurial': that inventors responded to market signals, that there was a corresponding investment in inventive activity and that inventors secured property rights in their inventions (in an effort to appropriate returns) ${ }^{87}$ In the case of antebellum America, they were able to demonstrate that both macro and micro-invention were the result of entrepreneurial behaviour on the part of inventors, and that this supported a demand-side interpretation of inventive activity. ${ }^{88}$

This paper has adopted a patent family analysis to examine the first and third conditions for a similar period in the United Kingdom and it has confirmed that inventors did respond to market signals and that they secured property rights in their inventions. In particular, the growth trend in Scottish and Irish patents closely matches the relative market potential for new industrial technology in both countries. When Scotland began to industrialise in the 1830s, so the number of patents increased dramatically and a relatively large proportion of Scots patents were in industrial sectors. A similar pattern occurred in Ireland after the Act of Union in $1800-$ although once Ireland was opened up to manufactured imports from the rest of the United Kingdom in 1826, precipitating a relative decline in Irish manufacturing, this growth ended. The final section of the paper confirmed the hypothesis that inventors were responding to market opportunities in two ways. Firstly, fluctuations in the patent count were shown to be pro-cyclical and secondly, patents extended to Scotland and Ireland were more valuable than those that were not.

The paper has not discussed the second condition proposed by Khan and Sokoloff, and the decision to obtain and/or extend patent protection is clearly not the same as the original decision to engage in an inventive activity - but they are analogous. Inventive activity during the Industrial Revolution was often expensive Richard Roberts calculated that the self-acting mule, patented in 1825 , had cost him nearly $£ 30,000$ to develop. ${ }^{89}$ The decision to engage in such a project would have required Roberts and his partners to estimate both the 'quality' or 'value' of the invention and the projected demand for it. Precisely the same factors would

87 Khan and Sokoloff $(1993,290)$.

88 Khan and Sokoloff $(1993,305)$.

89 For a long list of inventions and the amounts of money their development required, see Dutton (1984, 157-58). 
have concerned an inventor deciding to obtain or extend a patent, a decision that would require them to reckon the costs of protection compared with the potential returns. As in America, the behaviour of British inventors during the Industrial Revolution can be characterised as entrepreneurial and this means that the 'correct' incentive structure was an essential prerequisite for the development of industrial technology. This is not to suggest that commercial gain was the principal motivation for every inventor - how else to explain Humphry Davy's refusal to patent his safety lamp in 1815 - but that in the aggregate, inventive activity was primarily motivated by commercial gain.

\section{References}

Acemoğlu, D., 2002. Directed Technical Change, The Review of Economic Studies 69, 781-809.

Allen, R, C., 2009. The British Industrial Revolution in global perspective. Cambridge University Press, Cambridge.

Allen, R, C., 2009. The Industrial Revolution in miniature: The spinning jenny in Britain, France, and India. Journal of Economic History 69, 901-927.

Allen, R, C., 2011. Why the Industrial Revolution was British: Commerce, induced invention, and the scientific revolution. Economic History Review 64, 357-384.

Andrew, J., MacLeod, C., Stein, J., Tann, J., 2003. Evaluating inventive activity: The cost of nineteenth-century UK patents and the fallibility of renewal data. Economic History Review 56, 537-562.

Åstebro, T., 2003. The return to independent invention: Evidence of unrealistic optimism, risk seeking or skewness loving? The Economic Journal 113, 226-239.

Billing, S., and Prince, A., 1845. The law and practice of patents and registration of designs. Benning, London.

Bottomley, S., 2014. From privilege to property: The British patent system, 1700-1852. Cambridge University Press, Cambridge.

Broadberry, S., Campbell, B., Klein, A., Overton, M., van Leeuwen, B., 2011. British economic growth and the business cycle, 1700-1870.

Brown, A. L., 1964. 'The authorisation of letters under the great seal', Bulletin of the Institute of Historical Research 37, 125-156.

Brown, K. M., et al eds., 2007-2014, The Records of the Parliaments of Scotland to 1707, http://rps.ac.uk/ (accessed 4/4/2014).

Business and Intellectual Property Centre Archives (BIPC). Case book of James and Moses Poole, 1786-1825. BJ00 54889. British Library, London.

Chancery Archives (Chancery). Great Seal Register (Registrum Magni Sigilli) Paper Register, 1608-2008, C3. National Archives of Scotland, Edinburgh.

Crafts, N.F.R., 1985. British economic growth during the Industrial Revolution. Oxford University Press, Oxford.

Devine, T.M., 2004. Scotland. In: Floud, R., Johnson, P. (Eds.), The Cambridge economic history of Britain, Volume I, Industrialisation, 1700-1860. Cambridge University Press, Cambridge. pp. 388-416.

Dutton, H.I., 1984. The patent system and inventive activity during the Industrial Revolution. Manchester University Press, Manchester.

Federico, P., 1964. Historical patent statistics. Journal of the Patent Office Society 46, 89-171.

Geary, F., 1995. The Act of Union, British-Irish trade and pre-Famine deindustrialisation. Economic History Review 48, 68-88.

Geary, F., 1998. Deindustrialisation in Ireland to 1851: Some evidence from the census. Economic History Review 51, 512-541.

Gomme, A.A., 1937. Patent practice in the $18^{\text {th }}$ century: The diary of Samuel Taylor, threadmaker and inventor, 1722-1723. Journal of the Patent Office 19, 209-224.

Harhoff, D., Scherer, F., Vopel, K., 2003. Citations, family size, opposition and the value of patent rights, Research Policy 32, 1343-1363.

Hayward, P., 1987, Hayward's patent cases: 1600-1883, vol. 4. Professional Books Ltd, Abingdon

Hindmarch, W.M., 1846, Hindmarch's law of patents. Stevens, London.

Home Office Records (HO). Return to Parliament from the Rolls Office of the titles and dates of patents granted in Ireland for manufactures and inventions, 1700-1826, HO42/218.

Holroyd, E., 1830, The law and practice of patents for inventions. Strahans, London. 
House of Commons., 1829. Report from the Select Committee on state of law and practice relative to patents for inventions. (P.P. 1829, III).

House of Commons., 1849. Report of the Committee (appointed by the Lords of the Treasury) on the Signet and Privy Seal Offices. (P.P. 1849, XXII).

House of Commons., 1849. Number of letters patent for inventions, sealed in each of the ten years, ending 31 December 1847, together with the fees paid. (P.P. 1849, XLV).

House of Lords., 1851. Minutes of evidence taken before the Select Committee of the House of Lords appointed to consider the Bill to extend the provisions of the Design Act, 1850, and to give protection from piracy to persons exhibiting inventions in the Exhibition of 1851. (PP. 1851, XVIII).

House of Lords., 1851. Report and minutes of evidence taken before the Select Committee of the House of Lords appointed to consider of the Bills for the amendment of the law touching letters patent for inventions with appendix and index. (P.P. 1851, XVIII).

Hunt, E.H., 1985. Industrialization and Regional inequality: Wages in Britain, 1760-1914. Journal of Economic History 46, 935-966.

Khan, Z, B., Sokoloff, K, L., 1993. "Schemes of Practical Utility": Entrepreneurship and innovation among "Great Inventors" in the United States, 1790-1865. Journal of Economic History 53, 289-307.

MacLeod, C., 1988. Inventing the Industrial Revolution. The English patent system, 1660-1800. Cambridge University Press, Cambridge.

MacQueen, H.L., 2010. Intellectual Property and the Common Law in Scotland c.1700-c.1850. In: Bently, L., Ng, C., D'Agostino, G. (Eds.), The common law of intellectual property, essays in honour of Professor David Vaver. Hart, Oxford. pp. 21-44.

McCloskey, D., 2011. Bourgeois Dignity. Chicago University Press, Chicago.

Mitchell, B.R., 1988. British historical statistics. Cambridge University Press, Cambridge.

Mokyr, J., 1983. Why Ireland starved: A quantitative and analytical history of the Irish economy, 1800-1850. Routledge, Oxford.

Mokyr, J., 2005. The intellectual origins of modern economic growth. Journal of Economic History 65, 285351.

Mokyr, J., 2009. The Enlightened Economy: An Economic History of Britain, 1700-1850. Yale University Press, New Haven.

Moser, P., 2007. Why don't inventors patent? Working Paper 13294. National Bureau of Economic Research.

Nicholas, T., 2011. Independent invention during the rise of the corporate economy in Britain and Japan. Economic History Review 64, 995-1023.

Nuvolari, A., Tartari, V., 2011. Bennet Woodcroft and the value of English patents, 1617-1841. Explorations in Economic History 48, 97-115.

Ó Gráda, C., 1994. Ireland, a new economic history, 1780-1939. Clarendon, Oxford.

Officer, L., Williamson, S., 2014, Purchasing power of British Pounds from 1245 to present, MeasuringWorth, www.measuringworth.com/ppoweruk/ (accessed 18/4/2014).

Roberts, M., Shirley, E., 1852-67. Irish Chancery reports, vol. 1. Hodges, Smith \& Co, Dublin.

Romer, P., 1990. Endogenous Technological Change. Journal of Political Economy 98, S71-S102.

Sokoloff, K, L., 1988. Inventive activity in early industrial America: Evidence from patent records, 1790-1846. Journal of Economic History 48, 813-850.

Solar, P., 1990. The Irish linen trade, 1820-1852. Textile History 21, 57-85.

Sullivan, R., 1989. England's “Age of Invention": The acceleration of patents and patentable invention during the Industrial Revolution. Explorations in Economic History 26, 424-452.

Sullivan, R., 1990. The revolution of ideas: Widespread patenting and invention during the English Industrial Revolution. The Journal of Economic History 50, 349-362.

State Papers (SP). State Papers Domestic, George II, SP36. National Archives, London.

Van Pottelsberghe de la Potterie, B., Van Zeebroeck, N., 2008. A brief history of space and time: the scopeyear index as a patent value indicator based on families and renewals. Scientometrics 75, 319-338.

Van Zeebroeck, N., 2011. The puzzle of patent value indicators. Economics of Innovation and New Technology 20, 33-62.

Whatley, C.A., 1997. The Industrial Revolution in Scotland. Cambridge University Press, Cambridge.

Woodcroft, B., 1854. Titles of patents of invention chronologically arranged, 1617-1852. G.E. Eyre \& W. Spottiswoode, London.

Woodcroft, B., 1862. Reference index of English patents of invention, 1617-1852. G.E. Eyre \& W. Spottiswoode, London. 